\title{
The rediscovery of the São Tomé Grosbeak Neospiza concolor in south-western São Tomé
}

DAVE E. SERGEANT, TOM GULLICK, DON A. TURNER and J. C. (IAN) SINCLAIR

\section{Summary}

The São Tomé Grosbeak Neospiza concolor, previously known from three nineteenth century specimens from the southern part of São Tomé, was rediscovered in August 1991, when two birds were seen in a small clearing above the Rio Xufexufe in the remote forests in the south-west of the island.

O "Grosbeak de São Tomé" Neospiza concolor, do qual previamente se conheciam tres espécimes do século dezenove na parte sul de São Tomé, foi descoberto de novo em Agosto de 1991 quando dois pássaros foram vistos numa clareira acima do Rio Xufexufe nas remotas florestas do sudeste da ilha.

\section{Introduction}

The São Tomé Grosbeak Neospiza concolor, endemic to the island of São Tomé, was previously known from only three specimens collected by Francisco Newton in 1888 and 1890 . Only one specimen now remains (in the British Museum of Natural History), as the others were destroyed by a fire in the Bocage Museum, Lisbon, in 1975 (Collar and Stuart 1985). The type-specimen was collected at Angolares $\left(0^{\circ} 08^{\prime} \mathrm{N} 6^{\circ} 39^{\prime} \mathrm{E}\right)$ on the south-east coast in 1888 , with two further specimens taken from São Miguel and the Rio Quija (both $0^{\circ} 08^{\prime} \mathrm{N} 6^{\circ} 30^{\prime} \mathrm{E}$ ) on the south-west coast in 1890 . As all these locations are coastal, and the species was considered to inhabit forest, it had long been considered likely that the species could have become extinct (e.g. Snow 1950, King 1978-1979) owing to the clearance of lowland forest prior to 1975 when virtually all accessible areas of the island were cultivated for cocoa plantations. However, following independence from Portugal in 1975, clearance came to a halt and many plantations have now reverted to secondary forest. Natural forest cover on the island today is largely restricted to an area of the south-west of the island, bounded by the $4,000 \mathrm{~mm}$ isohyet (Jones and Tye 1988). The steep terrain and very high rainfall of this area (up to $10,000 \mathrm{~mm}$ annually) have combined to make study very difficult and, with two of the early specimens known from this region, there had always been a slim chance that the species could still survive (Collar and Stuart 1985). These forests have been considered the second most important forest area for threatened bird species in the Afrotropical and Malagasy region (Collar and Stuart 1988). 


\section{Survey area, habitat, rediscovery and description of Neospiza concolor}

The survey area - forest bordering the Rio Xufexufe - was chosen primarily as a result of preliminary work done by the 1990 University of East Anglia/ICBP expedition (Atkinson 1990, Atkinson et al. 1991), who had found most of the 25 known São Tomé endemic species there (in the following account, all coordinates are derived from the 1:25,000 Carta de São Tomé, Levantomento Aeropotogrametrico 1958, Folha 3, issued by the Ministério do Ultramar, Junta de Investigações do Ultramar). The Rio Xufexufe runs from the south-west coast $\left(0^{\circ} 9^{\prime} \mathrm{N} 6^{\circ} 31^{\prime} \mathrm{E}\right)$ inland in a north-easterly direction for about $7 \mathrm{~km}$ to its headwaters, and forms one of the principal drainages of the 1,400 $\mathrm{m}$ high Cabumé massif $\left(0^{\circ} 11^{\prime} \mathrm{N} 6^{\circ} 32^{\prime} \mathrm{E}\right)$. Access along the river was gained on foot, with local porters transferring equipment $3 \mathrm{~km}$ up the Rio Xufexufe to a base camp, which was used over 2-6 August as a central location from which to survey the river and surrounding forest. The camp was situated at $40 \mathrm{~m}$ altitude within undisturbed primary rainforest. Working the area was slow as the river course was comprised entirely of algae-covered volcanic boulders, with almost sheer forested slopes on either side. Over 5 days a total of $7 \mathrm{~km}$ of river was surveyed ( $5 \mathrm{~km}$ of the main Rio Xufexufe and $2 \mathrm{~km}$ along larger tributaries), with an altitude range of $\mathrm{o}-100 \mathrm{~m}$. Higher-altitude forest on the north-western side of the Rio Xufexufe was penetrated on three occasions by climbing the valley sides and walking along the less steep ridges. In this way, forest from $40-380 \mathrm{~m}$ altitude was covered.

The São Tomé Grosbeak was rediscovered whilst we were in the process of surveying the forests above the Rio Xufexufe. Birds were observed on two consecutive days $\left(0^{\circ} 09^{\prime} \mathrm{N} 6^{\circ} 31^{\prime} \mathrm{E}\right)$ on 4 and 5 August where they were perched in a bare tree along a ridge within closed-canopy primary forest at an altitude of $230 \mathrm{~m}$. On the first occasion, at o8h55 on 4 August, one bird was observed by DES and TG for about three minutes at $20 \mathrm{~m}$ distance: it was perched $4 \mathrm{~m}$ above eye level on a branch of a small dead tree at canopy level within a small clearing which had been created by a fallen tree. On the second occasion, the following day at IIhoo, DAT and JCS observed what was presumably the same and another bird briefly together, and then one alone for about 30 seconds, in exactly the same tree. Observations suggest that the species is a dweller in the canopy of primary forest, which almost certainly accounts for the paucity of records.

The most striking feature of the bird was the large "bull" head, "chunky" build, and very thick bill, giving an appearance reminiscent of Thick-billed Weaver Amblyospiza albifrons or European Hawfinch Coccothraustes coccothraustes. Size was estimated at $17-18 \mathrm{~cm}$. The whole upper parts were dark chestnut-black with no particular gloss. The underparts were similar, though more rufous. The bill was darkish horn, but leg colour was not readily discernible. The plate in Mackworth-Praed and Grant (1973) gives a fair impression of the species, although the head is more "bullish" than depicted. The voice was heard a few times during the first observations and consisted of a brief series of four or five short thin whistles uttered in a distinctly canary-like fashion. 


\section{Acknowledgement}

We wish to thank Phil Atkinson for his help in briefing us for the fieldwork.

\section{References}

Atkinson, P. (1990) University of East Anglia Expedition to São Tomé and Príncipe. JuneSeptember 1990. Unpublished preliminary report.

Atkinson, P., Peet, N. and Alexander, J. (1991) The status and conservation of the endemic birds of São Tomé and Príncipe, West Africa. Bird Conserv. Internatn. 1: $255-282$.

Collar, N. J. and Stuart, S. N. (1985) Threatened birds of Africa and related islands: the ICBP/ IUCN Red Data Book, Part I. Cambridge, U.K.: International Council for Bird Preservation.

Collar, N. J. and Stuart, S. N. (1988) Key forests for threatened birds in Africa. Cambridge, U.K.: International Council for Bird Preservation (Monogr. 3).

Jones, P. J. and Tye, A. (1988) A survey of the avifauna of São Tomé and Príncipe. Cambridge, U.K.: International Council for Bird Preservation (Study Report 24).

King, W. B. (1978-1979) Red Data Book, 2: Aves. Second edition. Morges, Switzerland: International Union for Conservation of Nature and Natural Resources.

Mackworth-Praed, C. W. and Grant, C. H. S. (1973) African handbook of birds, Series III: birds of West Central and Western Africa, 2. Edinburgh: Longmans.

Snow, D. W. (1950) The birds of São Tomé and Príncipe. Ibis 92: 579-595.

DAVE E. SERGEANT

34, Pine Walk, Weybourne, Holt, Norfolk, NR25 7HJ, U.K.

TOM GULLICK

India Alta, Infantes, Ciudad Real, Spain.

DON TURNER

P.O. Box 48019, Nairobi, Kenya.

J. C. (IAN) SINCLAIR

6 Lady Bruce Place, Roseglen, 4091 South Africa. 